\title{
Father Włodzimierz Ledóchowski (1866-1942): Driving Force behind Papal Anti-Communism during the Interwar Period
}

\author{
Philippe Chenaux \\ Pontifical Lateran University \\ chenaux@pul.it
}

\begin{abstract}
Włodzimierz Ledóchowski, superior general of the Society of Jesus, wielded great influence in the battle against Communism. His belief that there was a link of some degree between Jews and Communism, his work to establish a secretariat in Rome to counter atheistic Communism, and his influence in the development of the papal encyclical, Divini redemptoris, are explored in this article. Convinced that the Russian Revolution was a satanic force out to eradicate Christian society, Ledóchowski made it his life's work to expose the lies and threats of Bolshevism, culminating in his penultimate Congregation (in 1938) where the superior general discussed techniques that could be used to combat the spread of Communism.
\end{abstract}

\section{Keywords}

Communism - Bolshevism - anti-Semitism - Jesuit superior general - Włodzimierz Ledóchowski - Divini redemptoris

Father Włodzimierz Ledóchowski (1866-1942), elected twenty-sixth superior general of the Jesuits on February 11, 1915, was undoubtedly a key, and controversial, figure in the modern history of the Society of Jesus. ${ }^{1} \mathrm{He}$ was

1 As no true biography exists, please refer to Giacomo Martina's biographical notes: "Ledóchowski (Wlodimir), général de la Compagnie de Jésus (1866-1942)," in Dictionnaire d'histoire et de géographie ecclésiastiques, ed. Roger Aubert and Luc Courtois, Fascicule 180: Le Couëdic-Le Hunsec (Paris: Letouzey \& Ané, 2010), 54-62, and biographical information by

(C) CHENAUX, 2018 | DOI 10.1163/22141332-00501004

This is an open access article distributed under the terms of the prevailing CC-BY-NC license at the time of publication. 
born in Loosdorf, Lower Austria, on October 6, 1866, into an aristocratic Habsburg Empire family, entered the Society in 1889 following two years of study at the Gregoriana, and his ordination was on June 10, 1894. He was appointed the Society's provincial for Galicia before being named assistant general for the German provinces (Germany, Austria, Galicia, Hungary, The Netherlands, and Belgium) in 1906. His election during the second round of voting may have surprised many, given the circumstances, and was perceived by the French as a victory for Germany. ${ }^{2}$ The new superior general's decision to leave Rome as Italy joined the Allied forces and move to his family castle in Zizers, Switzerland, near Chur in Grisons township (where his mother, Countess Josephine de Salis, was born), only fueled suspicions. French and Allied intelligence services quickly suspected Ledóchowski was at the helm of a "widespread pacifist organization" subsidized by Berlin and Vienna, ${ }^{3}$ and the theory of a Jesuit-German alliance persisted throughout the war. Ledóchowski always expressed support for France during the conflict. Recently updated Russian documents project another image of the Society's superior general, however. During a meeting with a Russian government envoy who presented a proposal for an alliance with the Vatican in October 1916, Ledóchowski stated he was in favor of bringing the Catholic and Orthodox religions closer together. According to the Polish Jesuit, theological disputes between the two churches, such as the eleventh-century Filioque controversy and papal primacy, were outdated. The Catholic Church's best interests and preservation of its unity in Europe compelled Ledóchowski to develop closer ties with Allied countries (France

Wiktor Gramatowski: "Ledóchowski, Wlodimiro [Włodzimierz]" in Diccionario histórico de la Compañía de Jesús: Biográfico-temático, 2nd ed., ed. Charles E. O’Neil and Joaquín M. Domínguez (Rome: IHSI, 2001), 1687-90. See also the old biography by Giuliano Cassiani Ingoni, Vladimiro Ledóchowski: XXVI Generale d.C.d.G., 1866-1942 (Rome: Civiltà Cattolica, 1945) as well as the recent article by Marek Inglot, "Generalobere des Jesuitenordens Włodzimierz Ledóchowski (1866-1942)," in Faszinierende Gestalten der Kirche Oesterreichs, ed. Jan Mirkut, vol. 11 (Vienna: Dom Verlag, 2004), 231-46.

2 "Father Ledóchowski, Assistant for Germany, was elected Jesuit General over Father Fine, Assistant for France. Despite all the explanations, it was an Austro-German victory because the Ledóchowskis supported Austria. This did not sit well with the Jesuit community in France. Is everything conspiring to prevent our agreement with the Church?" Les Carnets du Cardinal Alfred Baudrillart, ${ }^{\text {er }}$ août 1914-31 décembre 1918, ed. Paul Christophe (Paris: Éditions du Cerf, 1994), 151.

3 This thesis is taken up without examination by Annie Lacroix-Riz in Le Vatican, l'Europe et le Reich de la Première Guerre mondiale à la guerre froide (Paris: Colin, 1996), 25. (All quotations in English are by the article translator, unless otherwise indicated.) 
and Russia). ${ }^{4}$ Even before being elected superior general, Ledóchowski was one of the Holy See's counselors for Russian affairs. ${ }^{5}$ This role became even more significant when the Bolsheviks came into power, ${ }^{6}$ and he would become the true driving force behind papal anti-Communism in interwar Rome. This article, based on documents from the Jesuit and the Vatican archives, ${ }^{7}$ is divided into four parts. In the first, I will examine Ledóchowski's views on the link between anti-Communism and anti-Semitism. In the second, I will examine his decision to establish a secretariat of modern atheism in Rome in October 1934 and in the third part, his role in formulating the Divini redemptoris encyclical (March 19, 1937). Lastly, I will look at the Thirty-eighth General Congregation (1938) debates on the fight against Communism.

\section{Anti-Communism and Anti-Semitism}

The First World War brought about a distinct resurgence in Western European anti-Semitism, and the notorious Protocols of the Elders of Zion was translated and circulated in the Western world in the aftermath of the war. This counterfeit document from Tsarist plagiarists appeared to confirm the reality of a global Jewish-Bolshevik conspiracy following the October Revolution. ${ }^{8}$ In a series of articles published in the early 1920s, the Jesuit journal in Rome, La Civilità cattolica, seemed to substantiate the reality of such a conspiracy. ${ }^{9}$ The journal's view of the February and October revolutions was close to that of reactionary

4 Philippe Chenaux, L'Église catholique et le communisme en Europe (1917-1989): De Lénine à Jean-Paul II (Paris: Éditions du Cerf, 2009), 60.

5 Laura Pettinaroli, La politique russe du Saint-Siège (1905-1939) (Rome: École française de Rome, 2016), 69 .

6 Friedrich Muckermann noted in his memoirs (Im Kampf zwischen zwei Epochen: Lebenserinnerungen [Mainz: Matthias-Grünewald-Verlag, 1973]) that Ledóchowski's influence increased over the years, remarkable as Pope Pius XI was not considered an "influenceable pope," 630-31.

7 Archivum Romanum Societatis Iesu (ARSI), Archivio Segreto Vaticano (AVs), Archivio della Congregazione per gli Affari Ecclesiastici Straordinari (AA.EE.ss.), and Archivio della Congregazione per la Dottrina della Fede (ACDF).

8 Cf. Norman Cohn, Histoire d'un mythe: La "conspiration" juive et les protocoles des sages de Sion (Paris: Gallimard, 1967). Translated by Léon Poliakov as Warrant for Genocide: The Myth of the Jewish World Conspiracy and the Protocols of the Elders of Zion (New York: Harper \& Row, 1966); Les "Protocoles des Sages de Sion," ed. Pierre-André Taguieff, 2 vols. (Paris: Berg, 1992).

9 "La rivoluzione mondiale e gli ebrei," in La Civiltà cattolica 73, no. 4 (1922): 111-21, here 2. Cf. Philippe Chenaux, "Die Gesellschaft Jesu und die Rassendebatte in den $1920^{\text {er }} 193^{\text {er }}$ Jahren," Römische Quartalschrift 110, no. 3-4 (2015): 251-61. 
Russians: it was inclined to attribute a decisive role in the uprisings to what was called "International Jewry." Did the overrepresentation of Jews in the revolution's leadership - seventeen out of twenty-one, according to the Council of People's Commissars-not seem to make Bolshevism a simple variant of international Judaism? Italian historian Giovanni Miccoli clearly demonstrated that Jews were relatively absent from the debate surrounding the origins of the French Revolution. They, for instance, played no role in the prominent 1802 Memoirs Illustrating the History of Jacobinism by Abbé Augustin Barruel (1741-1820), which was long used as a reference for interpreting facts. It was only in the 1870 ond 188 os that Jews started to emerge as major players in antiChristian conspiracies: certain elements of the Catholic press disseminated the concept that Jews were not only "the greatest benefactors of the Revolution" (through emancipation laws), but also "its true hidden architects." ${ }^{10}$

At the very least, the general of the Society of Jesus did not dissociate himself from these attacks against Jews and took every opportunity to mention the existence of a "Jewish peril" in private conversations. Evidence appears in this conversation with Alfred Baudrillart (1859-1942), rector of the Catholic University of Paris (ICP) and future cardinal, on April 29, 1922:

Lengthy meeting with Fr. Ledóchowski, Jesuit general. He's a true Pole: charming, seductive, with simple ways, and talks a lot. Spent forty minutes with him. He spoke a lot about the Jewish organization in Poland and Russia as well his relationship with the Bolshevik movement. He's convinced that the organization is out to destroy Christian society. ${ }^{11}$

The same ideas were expressed in a note sent to Cardinal Secretary of State Pietro Gasparri (1852-1934) prior to the Genoa Economic and Financial Conference in May 1922. Mentioning Soviet leaders' "treachery proven by facts," the Jesuit official wrote:

We need to realize that Russia's current revolutionary government did not stem from its economic and social conditions, as in other revolutions, but is a foreign, Jewish government with an impressive, international

10 Giovanni Miccoli, "Un nouveau protagoniste du complot antichrétien à la fin du XIxème siècle," in Juifs et chrétiens: Entre ignorance, hostilité et rapprochement (1898-1998), ed. Annette Becker, Danielle Delmaire, and Frédéric Gugelot (Villeneuve d'Ascq: Université Charles-de-Gaulle, 2002), 22.

11 Paul Christophe, ed., Les Carnets du Cardinal Alfred Baudrillart ( ${ }^{\text {er }}$ janvier 1922-12 avril 1925) (Paris: Éditions du Cerf, 2001), 164. 
organization that has set out to destroy Christian civilization and ensure absolute world domination for the Israelites. ${ }^{12}$

The Society's general was convinced that the Bolshevik Revolution was a satanic operation carried out by Israelites to "destroy Christian society." He was therefore skeptical of the Vatican's attempt to negotiate a modus vivendi with the Bolshevik government to guarantee essential freedoms to the Russian church. When Vatican authorities prepared to reach out to Soviet diplomats during the May 1922 Genoa conference, the general was unconvinced. While expressing appeasement, the Holy See had to act "inflexible" in defending the principle of freedom of conscience. ${ }^{13}$ The memorandum the Holy See messenger sent to delegates had no direct impact on the conference proceedings, but compelled Soviet delegate Georgy Chicherin (1872-1936)—whom Monsignor Giuseppe Pizzardo (1877-1970) met in Santa Margherita Ligure on May 8,1922 - to reaffirm in a press release that religious freedom was a respected right in the Soviet Union in accordance with the law. ${ }^{14}$ In July 1924, the superior general returned to the fray when the Vatican began negotiations with the Soviet government through Berlin nuncio Monsignor Eugenio Pacelli (18761958, r.1939-58) to reach a modus vivendi guaranteeing freedom for the Catholic Church. In a letter to Pius XI (Ambrogio Damiano Achille Ratti, 1857-1939, r.1922-39), Ledóchowski asked the pope to "reveal" to the world the "lies" and "perverseness" of "Soviet leanings." ${ }^{15}$ Allusions to Bolshevik "lies," "created and

12 "Pare che sia necessario di avere sempre avanti gli occhi che il presente governo rivoluzionario della Russia non sia, come accade nelle altre rivoluzioni, nato dalle condizioni economiche e sociali del paese stesso, ma un governo straniero, giudaico con una organizzazione splendida internazionale che tende a distruggere la civiltà cristiana e assicurare agli israeliti la dominazione assoluta del mondo," Ledóchowski to Gasparri, May 13, 1922, AA.E E.ss., Russia, fasc. 13 .

13 Fr. Ledóchowski's instructions for his trip to Genoa on May 4, 1922, AA.EE.ss., Russia, fasc. 49 .

14 The January 23, 1918, decree with respect to separating church and state.

15 "Invece, essendo stato tutto questo movimento creato e diretto fin da principio dagli ebrei, ed essendo questi nemici implacabili del nome cristiano sparsi per tutto il mondo, i Sovieti aiutati dai loro connazionali fanno in tutte le regioni una propaganda incredibile, adattandosi con somma perspicacia e scaltrezza alle condizioni dei vari paesi per farvi entrare cautamente ma sicuramente le loro idee. Da tutte le parti del mondo, dall'Europa, dall'Asia, dall'Africa, fanno a loro spese venire a Mosca dei giovani e delle giovanette per corromperli e riempirli di fanatismo, con quel talento che è così proprio della razza ebrea, e poi rimandarli nei loro paesi come fedeli propagatori del comunismo russo," Ledóchowski to Pius XI, Rome, July 6, 1924, AA.EE.ss., IV, Russia, pos. 659, fasc. 44, 
directed by Jews," and "relentless enemies of Christians," were once again a testimony to an obsessive anti-Semitism by the Society of Jesus's general. ${ }^{16}$

When the Congregation of the Holy Office published a decree on March 25,1928 , to condemn "this hatred against the people once chosen by Godhatred commonly called 'anti-Semitism' today," Jesuits in Rome hastened to play down the impact of this condemnation. The decree ordered the Friends of Israel, an association created two years prior to promote a new attitude among priests towards Israel and to eliminate anti-Judaism in the Catholic liturgy, to be disbanded. This new attitude was not based on hatred or distrust; instead, it was founded on understanding and love. As Holy Office records show, the association was dissolved for having the audacity to ask for the expression "pro perfidis Iudaeis" (for the treacherous Jews) to be removed from the Good Friday liturgy and for genuflection, removed in the Middle Ages, to be reinstated. ${ }^{17}$ La Civilità cattolica commented on this decree, attempting to explain that anti-Semitism was not being condemned in and of itself; rather, it was its excess of radical, extreme anti-Semitism spreading through a few Catholic fundamentalist circles that was incompatible with the Christian spirit. Such condemnation did not take anything away from the reality of the "Jewish peril" threatening Christians, especially Latin and Catholic peoples who must fight the threat. The distinction between two forms of anti-Semitism-on the one hand, a racial, "anti-Christian" anti-Semitism that was formally prohibited, and on the other hand, a political, legal anti-Semitism that was an "authorized" and encouraged practice - would be reinstated and made official by Gustav Gundlach (1892-1963), another Jesuit, in a notice in Lexikon für Theologie und Kirche (1939). ${ }^{18}$ One can easily find more open attitudes to Judaism within the Society. Pierre Charles (1883-1954), a Belgian Jesuit and missiology professor at

71-73). The document is an annex to the electronic version of Laura Pettinaroli's "La politique russe du Saint-Siège (1905-1939)" thesis.

16 Read about this topic in Daniele Menozzi's "Giudaica perfidia": Uno stereotipo antisemita fra liturgia e storia (Bologna: Il Mulino, 2014).

17 ACDF, Rerum variarum, 1928, n. 2, vol. 1. For information on the decree's origins: Philippe Chenaux, "Le Saint-Siège et la question de l'antisémitisme sous le pontificat de Pius XI," Revue d'histoire ecclésiastique 99, no. 3-4 (2004), 700-22; Hubert Wolf, "Pro perfidis Judaeis: Die 'Amici Israel' und ihr Antrag auf eine Reform der Karfreitagfürsbitte für die Juden (1928); Oder: Bemerkungen zum Thema katholischen Kirche und Antisemitismus," Historische Zeitschrift 279 (2004): 611-58.

18 Gustav Gundlach, "Antisemitismus," in Lexikon für Theologie und Kirche, 1st ed. (Freiburg im Breisgau: Herder-Verlag, 1930), cols. 504-5. Cf. Johannes Schwarte, Gustav Gundlach S.J. (1892-1963): Massgeblicher Repräsentant der Katholischen Soziallehre während der Pontifikate Pius XI und Pius XII (Munich: F. Schöningh, 1975). 
Université Catholique de Louvain, was one of the first to condemn the falsehoods and inconsistencies in the Protocols of the Elders of Zion. ${ }^{19}$ Pope Pius XI worried about anti-Semitic legislation in Italy and asked American Jesuit John LaFarge (1880-1963), author of Interracial Justice (1937), to write an encyclical against racism and anti-Semitism. The project was developed with help from two colleagues, Gundlach and Gustave Desbuquois (1869-1959), and submitted to Ledóchowski at the end of the summer of 1938 , but was never published. ${ }^{20}$

\section{Secretariat of Modern Atheism}

The year 1930 was undoubtedly a turning point in Vatican politics pertaining to the Soviet Union. Until then, the search for some sort of agreement, or modus vivendi, with the Russian government had been tirelessly pursued by Rome, despite persecution and provocation. The failure of a reluctant Monsignor Pacelli's negotiations in Berlin between 1924 and 1927 and the Kremlin's hardened antireligious stance led the pope and his colleagues to review their strategy. It should be noted that, in 1929, a "second major offensive by the Soviet State against the Church" was mounted, following the first offensive from 1918 to 1922. On a legislative level, the offensive consisted of liberalizing antireligious propaganda (the April 8, 1929 decree) and establishing a five-day continuous workweek that "excluded Sunday as a common day of rest for the entire population."21 This campaign reached its peak during Christmas celebrations in 1929, which were punctuated by numerous incidents and the closure of hundreds of churches and places of worship (especially Orthodox institutions) in the following weeks. Reaction from the Holy See was swift. A public letter to Basilio Pompilj (1858-1931), cardinal-vicar of Rome, on February 2, 1930, from Pius XI signaled the start of a counter-offensive defending "divine rights denied in Russia." The pope alluded from the beginning to his own "efforts" and those of his predecessor to "stop the appalling persecution and divert tragedy for countless people." He particularly regretted the missed opportunity at the

19 Pierre Charles, "Les protocoles des sages de Sion," Nouvelle revue théologique 65 (1938): 56-78, 966-69, 1083-84 (article in three parts).

20 Cf. Georges Passelecq and Bernard Suchecky, L'encyclique cachée de Pie XI: Une occasion manquée de l'Eglise face à l'antisémitisme (Paris: La Découverte, 1995). John LaFarge, Interracial Justice (New York: America Press, 1937).

21 Nicolas Werth, "Un État contre son peuple: Violences, répressions, terreurs en Union soviétique," in Le Livre noir du communisme: Crimes, terreur, répression, ed. Stéphane Courtois (Paris: Robert Laffont, 1998), 41-295 (15 chapters), here 201-3; Adriano Roccucci, Stalin e il patriarca: La Chiesa ortodossa e il potere sovietico (Torino: Einaudi, 2011), 61-116. 
Genoa conference to "agree on a joint declaration that would have saved Russia and other parts of the world much misfortune." Highlighting the "resurgence" of atheist campaigns, such as sacrilegious attacks and official blasphemous advertising, he insisted on "more universal and formal reparation." ${ }^{22}$ Pius XI's increasing intercession from 1930 on clearly signaled an overarching plan to counter propaganda from the "sans Dieu" (godless). ${ }^{23}$ The Third International's battle to export the revolution around the globe was indeed a religious war specifically targeting Catholicism. That was the essence of the message in a memo on Communist propaganda sent to all nuncios in April 1932:

The party's organisms, and particularly directives sent to leaders, repeat that the strength of all religions would be destroyed if the Catholic Church, first and foremost the Holy See, were cut down. The fight is therefore particularly focused, in and outside Soviet Russia, against everything that is Catholic, even if it must resort to temporary allies such as anti-Catholic factions, militant Protestantism, Freemasonry, and atheist and antireligious liberalism. ${ }^{24}$

The church was directly threatened. Consequently, the Holy See wanted to know precisely (con esattezza) how communist propaganda was progressing in each country. Its international representatives were asked to provide a detailed report as soon as possible. "The task is delicate and laborious," wrote Cardinal Pacelli, "but necessary for the salvation of souls, the Church, and the Society." ${ }^{25}$ A draft encyclical, De divinis humanisque iuribus in Russiarum regionibus impiissime violatis, is preserved in Pius XI's personal archives (spoglio). Dated December 1932, it was addressed to all patriarchs, primates, archbishops, priests, and ordinaries in peace and communion with the Holy See. It confirmed the pope could not "remain silent" before the gravity of crimes

22 AA.Ee.ss., Stati eccl., fasc. 73 .

23 Michel d'Herbigny, Les "Sans Dieu" militants et la propagande mondiale du communisme (Paris: Fédération nationale catholique, n.d.), considers two articles published in $\mathrm{La} \mathrm{Re}$ vue des deux mondes (February 1 and 15, 1933).

24 "Le organizzazioni del partito e più ancora le direttive inviate ai Capi ripetono costantemente che la forza di tutte le religioni sarebbe distrutta, se la Chiesa cattolica e in primo luogo la Sede apostolica fosse abbattuta. La lotta è dunque concentrata, dentro e fuori della Russia sovietica, in modo speciale contro tutto ciò che è cattolico, anche se occorresse di servirsi, come di alleati provvisori, delle sette anticattoliche, del protestantesimo militante, della massoneria, del liberalismo ateo e antireligioso," Asv, Arch. Nunz. Parigi, fasc. 469 .

25 Pacelli to Maglione, April 14, 1932, Asv, Arch. Nunz. Parigi, fasc. 469. 
committed in Russia and everywhere else. ${ }^{26}$ The encyclical was never published for reasons still unknown. It does not appear that there was any direct link between this encyclical against crimes in Soviet Russia and the encyclical Divini redemptoris (March 19, 1937), which clearly had a "Jesuit" origin.

The decision by Ledóchowski to establish a secretariat of modern atheism was at the root of this encyclical. In January 1933, Joseph Ledit (1898-1986), a French-American Jesuit, wrote a memo to Ledóchowski on "how to fight against Bolshevik propaganda." ${ }^{27}$ In this memo, the Jesuit, who taught Russian history at the Pontifical Oriental Institute following a short stay in the Soviet Union a few years prior, insisted on the need to "prepare Catholic specialists" who could "refute Bolshevism through Bolshevist publications." ${ }^{28} \mathrm{He}$ mentioned that the Pontifical Oriental Institute had "a wealth" of rarely used documentation that would prove "immensely helpful if someone was assigned to put the topic under the spotlight." He could foresee the eventual "creation of an information center on Soviet international propaganda in Rome." With a network of correspondents in all Society provinces, the center could feed the Catholic press around the world. ${ }^{29}$ The general endorsed the project, if we are to believe a letter sent to North American and Canadian provincials in April 1934. Just as the Society of Jesus had been founded in the sixteenth century to fight against Protestant heresy, it was being called upon once again to fight the Communist heresy, "more dangerous perhaps than any heresy of the past [...]. For Communism is not merely a system of philosophy, an abstract theory fostered by scattered groups of men; it is a world-force powerfully organized, and even now actively at work in various countries with incalculable harm to souls and to religion." 30

To carry out the Society's project of systematic global warfare against Christianity and civilization's common enemy, the general asked each province to designate a priest to gather information and ensure all activities required

26 AA.EE.ss., Stati eccl., pos. 662 , s.n.

27 "Sur la manière de lutter contre la propagande bolchevique," January 8, 1933, ARSI, Secretariatus pro communicatione sociali, 1038 (De comm. atheo).

The purpose of Ledit's trip to Russia with Joseph M. Schweigl (1894-1964), an Austrian colleague, was to set up a Catholic seminary in Odessa. The mission failed miserably. Both Jesuits were arrested and expelled from Soviet territory. Cf. Vincenzo Poggi, "Joseph Ledit S.J. (1898-1986): Journal d'une mission en Russie (1926)," Orientalia christiana periodica 53 $(1987): 5^{-40 .}$

29 "Sur la manière de lutter contre la propagande bolchevique," January 8, 1933, ARSI, Secretariatus pro communicatione sociali, 1038 (De comm. atheo).

30 Letter, April 17, 1934, ARSI, Secretariatus pro communicatione sociali, 1038 (De comm. atheo). 
for this battle were successfully completed. ${ }^{31}$ "The project had something magnificent about it: Rome was going to be the center of the 'Catholic International,' just as Moscow was the center of 'Ideology International' and Geneva the center of world politics. The project rallied the entire order."32 One of the essential conditions of the plan's success, Ledit wrote in a new memo to Ledóchowski, was to "avoid rumors and publicity" and keep all activity in the hands of the Society's superior (in manu superioris). ${ }^{33}$ At the end of October 1934, Ledóchowksi announced to his collaborators the establishment of a secretariat against modern atheism to be led by Ledit. Its objectives were those of an actual Roman center for counter-propaganda against Moscow's atheism. ${ }^{34}$

The first issue of Lettres de Rome sur l'athéisme moderne (Letters from Rome on modern atheism) was published in May $1935 .{ }^{35}$ "We felt that there was an urgent need for a publication that was Catholic, international, and that specifically focused on militant atheism," they wrote. ${ }^{36}$ The magazine was published in three languages (aside from the original French edition, there was a publication in Spanish, Cartas de Roma, and a publication in English, The World's Problem), which were read by more than one thousand subscribers in $1936 .{ }^{37}$ The secretariat put together impressive documentation on the international communist movement (journals, booklets, and leaflets) with the help of a small team that included German anti-Nazi Jesuit priest Friedrich Muckermann $\left(1883^{-1946)}\right)^{38}$ The material was first exhibited at the Russicum in September 1936. This was followed by a second exhibition in March 1938 for the Society of

$31 \quad$ Ibid.

32 Giorgio Petracchi, "I gesuiti e il comunismo tra le due guerre," in La Chiesa cattolica e il totalitarismo, ed. Vincenzo Ferrone (Florence: Olschki, 2004), 141.

"Pour organiser la lutte contre l'athéisme militant," Letter, October 2, 1934, ARSI, Secretariatus pro communicatione sociali, 1038 (De comm. atheo).

34 Ad Patres qui in provinciis pugnam contra atheismum dirigunt ac promovent, Rome, October 28, 1934, ARSI, Secretariatus pro communicatione sociali, 1038 (De comm. atheo).

The magazine's title could not fail to implicitly remind readers about the antimodernist fight, led from the start of the century by Umberto Benigni's Correspondance de Rome magazine. See Pettinaroli, La politique russe du Saint-Siège, 724.

36 "Il nous a semblé que le besoin urgent se faisait sentir d'une publication qui fut en même temps catholique, internationale, et étudierait spécialement l'athéisme militant." Joseph Ledit, "Notre raison d'être," Lettres de Rome sur l'athéisme moderne (May 1935), 1.

37 Petracchi, "I gesuiti e il comunismo," 143.

38 The Jesuits obtained a special permit from Italian police, allowing them to disregard Fascist censorship and establish their documentation center. See Filippo Frangioni, "La papauté, le communisme et Divini redemptoris," in Pie XI, un pape contre le nazisme? L'encyclique "Mit brennender Sorge", ed. Fabrice Bouthillon and Marie Levant (Brest: Éditions Dialogues, 2016), 130. 
Jesus's Twenty-eighth General Congregation. ${ }^{39}$ Although we still lack a comprehensive review, the influence of this network was far from insignificant. Pius XI naturally turned to this small group of Jesuits when he thought about publishing an encyclical against godless, atheistic Communism. ${ }^{40}$

\section{The Divini redemptoris Encyclical (March 19, 1937)}

Ledóchowski was the first person to come up with the idea of a Divini redemptoris encyclical in a letter to Pius XI in April $1936 .^{41}$ For the Jesuit general it was nothing less than organize the resistance of Catholics and the entire world to "Moscow's atheist propaganda," at a time when this propaganda was "more skillful and deceitful," by telling "the whole truth" about Communism and the "atrocities committed" in Russia's name in Mexico via Spain. "Forgive my boldness, but if Your Holiness thought it was an appropriate time to write such an encyclical, I think we could provide useful material from a variety of countries." ${ }^{42}$ As we will see, the Jesuit's offer did not go unheeded. The Society of Jesus's superior general did not ignore the work that a Holy Office commission, partially composed of Jesuit theologians, undertook to condemn another "heresy" of the times: pagan national socialism. ${ }^{43}$ Adolf Hitler's (1889-1945) accession to power in Germany in January 1933 led German bishops to temporarily halt attacks on Nazi ideology. The new chancellor's declared intent to defend Germany's Christian heritage and fight Bolshevism had even impressed Pius XI. Despite signing the agreement between the Holy See and German Reich in July 1933, Rome remained vigilant concerning Nazism. Putting two important books, Der Mythus des 20. Jahrhunderts (1930) by Alfred Rosenberg (1893-1946) and Der deutsche Nationalkirche (1933) by Ernst Bergmann (1881-1945), on the Index in

39 Joseph Ledit, La stampa comunista nel mondo: Guida alla mostra allestita dalla redazione "Lettres de Rome" (Rome: SDA, 1938, and ARSI, Secretariatus pro communicatione sociali, 1038, [De comm. atheo]).

40 In 1938, forty-five apostolic and nunciature delegations would resubscribe to Lettres de Rome at the secretary of state's expense (Pettinaroli, La politique russe du Saint-Siège, 724-25).

41 Manuscript letter, April 11, 1936, AA.EE.ss., Stati eccl., fasc. 577.

42 "Vostra Santità mi perdonerà il mio ardire e se credesse opportuno di scrivere una tale Enciclica, credo che potremmo anche noi contribuire qualche materiale utile di diversi paesi," ibid.

43 Cf. Philippe Chenaux, "Aux origines de la Mit brennender Sorge: un Syllabus contre l'hérésie nationale-socialiste (1933-1937)," in Pie XI, un pape contre le nazisme? 109-21. 
February 1934 clearly showed a firm resolve regarding doctrine. ${ }^{44}$ In October 1934, the Congregation of the Holy Office was shaken by a report from one of its consultants, Austrian bishop Alois Hudal (1885-1963), rector of the German college Santa Maria dell'Anima since $1923 .{ }^{45}$ Though Hudal got along with the new regime and wanted to build a stronger relationship, he condemned the dangers of racism, radical nationalism, and state totalitarianism, and asked for these "three modern heresies" to be censured by "an encyclical" or "an equivalent updated syllabus similar to that of Pope Pius IX."46 When he read the report, Pius XI decided to entrust this "thorny issue" to the Jesuits. Three Society theologians developed a catalog of propositions to condemn: nationalism (eight items), idolization of race (twenty-four), and totalitarianism (fifteen). ${ }^{47}$ The involvement of the secretariat of state, which had been excluded until that point, would prove to be decisive. In a votum dated April 20, 1936, Monsignor Domenico Tardini (1888-1961) explained that it was no doubt appropriate to condemn the "serious" and "dangerous" mistakes of racist nationalism, but Communism must not be forgotten. The world was divided into two camps: nationalism and Communism. It was important to prevent an eventual doctrinal "condemnation" from being perceived as a "political act" in favor of one of the two camps (the communist camp, in this instance). The best way to avoid this trap was to condemn both systems. "They have many points in common," the Vatican prelate wrote, clearly influenced by certain analyses of similarities between the two totalitarianisms. ${ }^{48}$ This condemnation might take the form of the one Pius IX used against liberalism and Pius X (Giuseppe Melchiorre Sarto, 1835-1914, r.1903-14) used against modernism: a doctrinal encyclical followed,

44 Cf. Dominik Burkard, Häresie und Mythus des 20. Jahrhunderts: Rosenbergs nationalsozialistische Weltanschauung vor dem Tribunal der Römischen Inquisition (Paderborn: Schöningh, 2004). Alfred Rosenberg, Der Mythus des 20. Jahrhunderts: Eine Wertung der seelisch-geistigen Gestaltenkämpfe unserer Zeit (Munich: Hoheneichen, 1930).

45 Philippe Chenaux, "Pacelli, Hudal et la question du nazisme (1933-1938)," Rivista di storia della Chiesa in Italia 57 (2003): 133-54.

46 Hudal to Sbarretti, Secretary to the Congregation of the Holy Office, October 7, 1934, ACDF, Rerum variarum, 1934, n. 29, vol. 1, 1-5.

47 Elenchus propositionum de nationalismo, stirpis cultu, totalitarismo, ACDF, Rerum variarum 1934, n. 29, vol. 1.

48 These theses are defended in Catholic circles by Waldemar Gurian (1902-54), a converted Jew. His work Der Bolschewismus: Einführung in Geschichte und Lehre (Freiburg im Breisgau: Herder, 1931) was translated into English as Bolshevism: Theory and Practice, trans. Edward Ingram Watkin (London: Sheed \& Ward, 1932) and into Italian as Il bolscevismo, trans. Teocrito di Giorgio (Milan: Vita e pensiero, 1933). 
or preceded, by a catalog of condemned mistakes..$^{49} \mathrm{~A}$ new commission was established on April 29, 1936, based on these observations. ${ }^{50}$ The commission's mission was to "study Communism" (which, as we have seen, had not previously been done) and put together a two-part document. The first part of the document would examine errors and Catholic doctrine; the second part, a list of incorrect proposals to condemn. Commission members were advised to focus on "fundamental mistakes, excluding false or blasphemous ones" and come up with clear and precise wording, "avoiding excessive Scholastic language, which is rarely understood by the general public."51 After meeting several times (at least seven between May and June 1936), the commission developed a draft decree in four parts. It denounced racism, hyper nationalism, Communism, and totalitarianism, but never saw the light of day. ${ }^{52}$ When Holy Office cardinals were asked in November 1936 to determine the advisability of such a condemnation, they judged it was better, under the circumstances, to postpone its publication. At best, the cardinals acknowledged the usefulness of pastoral action to "warn the faithful about Communist errors." Pius XI approved their decision and promised "he would do something." ${ }^{3}$ The strategy of prudence must have won over Pius XI, as striking a decisive blow against heresies of the time was no longer a consideration. ${ }^{54}$ The Divini redemptoris encyclical was published four months later on March 19, 1937, and condemned atheist Communism, which was defined as "intrinsically perverse." Documents now accessible from the Vatican archives reveal the origins of this significant text more clearly by bringing to light the decisive role Ledóchowski and the team from The World's Problem played in its creation.

The draft the Jesuits worked on with Ledóchowksi in Rome was sent to Pius XI in February 1937. The text has not been preserved in the Vatican archives,

49 Nazionalismo, razzismo, stato totalitario: Voto dell'Eccm. Mons. Tardini, April 20, 1936, ACDF, Rerum variarum 1934, n. 29, vol. 2.

5o Monsignors Ottaviani (assessor), Ruffini, Tardini, Perugini, Parente, Fathers Gillet (Dominican), Chagnon, Herman, Hürth, and Ledit (all Jesuits) were the commission members. Nota d'ufficio, ACDF, Rerum variarum 1934, n. 29, vol. 2.

$51 \quad$ Nota d'ufficio, ACDF, 1.

52 Razzismo, nazionalismo, comunismo, totalitarismo, ACDF, Rerum variarum 1934, n. 29, vol. 4, fasc. 12. Appendices included many texts from Hitler (Mein Kampf), Mussolini, Lenin, Marx, and Engels.

53 Feria IV, 18 novembris 1936; Ex. Aud. ssmi Feria Va die 19 novembris 1936, ACDF, Rerum variarum 1934, n. 29, vol. 4.

54 Peter Godman, Der Vatikan und Hitler: Die geheimen Archive (Munich: Droemer, 2004). Translated into English as Hitler and the Vatican: Inside the Secret Archives That Reveal the New Story of the Nazis and the Church (New York: The Free Press, 2004), 139. 
though various other documents allow us to see clearly the specific contribution the Society and its general made to writing the encyclical. Unlike the Holy Office, Roman Jesuits saw Communism as the main, if not the only, danger for the church. The notion of similarities between red and brown totalitarianisms was not a factor in the Jesuits' analyses. ${ }^{55}$ Their approach to the phenomenon of Communism was more political than doctrinal, focused more on deeds than on texts. "We must avoid giving the widely held impression that the Church is satisfied with fine words without ever taking action," wrote Ledóchowski in a background memo to the pope ${ }^{56}$ For the Jesuits, the topic of the encyclical was not so much the Marxist-Leninist doctrine and its materialistic philosophical assumptions, but the Communist system itself as practiced in the Soviet Union and its global aspirations. As we have seen, the Jesuits had abundant documentation available, collected by the Roman secretariat on atheism. Be it Joseph Ledit or Friedrich Muckermann, the priests who prepared the encyclical belonged to the Lettres de Rome team. ${ }^{57}$ Only Desbuquois, director of Action Populaire, who had been called urgently to Rome at the beginning of February, was from elsewhere. According to his biographer, Desbuquois had a hard time getting the project, which he considered "too negative," back on track. ${ }^{58}$ The Action Populaire director's views on the Communist danger were more moderate than the Jesuit general's. During the magazine directors' meeting in Rome during the World Exposition of the Catholic Press in May 1936, Desbuquois was soundly rebuked by Ledóchowski for daring to suggest the possibility of dialogue with Communists. ${ }^{59}$ Another difference of opinion between the two lay in the role of Jews in the international Communist movement. "We deemed it necessary to include a passage in the encyclical on Jewish influence, however subtle or allusive, not only because key Communist thought leaders such as

55 In his memoirs, Muckermann mentioned that his idea of expanding the Lettres de Rome program to focus on Nazism and Fascism "was not highly regarded." Muckermann, Im Kampf zwischen zwei Epochen, 626.

56 "Bisogna evitare l'impressione, che si va sempre più diffondendo che la Chiesa si pasce di buone parole, ma non arriva ai fatti," Ledóchowski to Pius XI, February 24, 1937, AA.E E.ss., Stati eccl., fasc. 574 .

57 Judging by Ledit's later account, Muckermann was assigned the writing tasks (letter, August 8, 1964, Stati eccl., fasc. 577, f. 10).

58 See Paul Droulers, Politique sociale et christianisme: Le Père Desbuquois et l'Action populaire, vol. 2 (Paris: Éditions ouvrières, 1981), on the role of Desbuquois. Action Populaire put out a large "inquiry into communism" in June 1936. More than ten thousand copies of "Enquête sur le communisme" (Investigation into Communism) were published Paris in 1937.

Droulers, Politique sociale et christianisme, 191-92. 
Marx and Lassalle were Jewish, but also because the Communist movement in Russia was directed by Jews. Even now, if you look behind the scenes and get to the heart of the matter, the Jews are the most active supporters and promoters of Communist propaganda," wrote Ledóchowski. Pius XI would not concur with the "Black Pope" on this point. ${ }^{60}$ When the encyclical was published, the Jesuit general convinced the pope to quickly publish the Italian text with the Latin. "It seems appropriate to have an approved modern-language text in an official document that could be used in the future to compare and clarify a point under discussion in schools of sociology." ${ }^{\prime 1}$

\section{The 1938 General Congregation}

Historians have severely criticized Ledóchowski's attitude during the final months of Pius XI's reign. He has generally been blamed for doing everything in his power to delay publication of the encyclical against racism and antiSemitism that Pope Pius XI had asked LaFarge to write. ${ }^{62}$ The Polish general believed that Communist atheism was the enemy he had helped condemn in the encyclical Divini redemptoris. "He is just as worried as I am about the future, and he believed that we are undergoing a widespread and radical revolution that will surpass all that have preceded it," wrote Cardinal Baudrillart following a long meeting with Ledóchowski in March $1937{ }^{63}$ Not all Jesuits

6o "Ci parve necessario che in una tale Enciclica si faccia, sia pure di passaggio e velatamente, almeno un'allusione all'influsso ebraico, essendo certo che non solo gli autori intellettuali del comunismo (Marx, Vassalle ecc.) erano tutti ebrei, ma anche il movimento comunista in Russia è stato inscenato da ebrei, e adesso pure, benché non sempre apertamente, in tutte le regioni, se si va ben a fondo, sono gli ebrei i primi fautori e promotori della propaganda comunista," AA.E E.Ss., Stati eccl., fasc. 574. The pope wrote the following in the margin of the text: "check" (verif.), a way of distancing himself from Ledóchowski's obsession with anti-Semitism. Desbuquois's biography credits Desbuquois with the removal of the reference to Jews in the final text. Droulers, Politique sociale et christianisme, 197 n256.

61 Letter, March 29, 1937, AA.EE.ss. Russia, fasc. 575.

62 Apparently, no document regarding this matter was saved in the Society's archives. According to Désiré Lamalle (1915-96), former archivist, an absence of documents was not surprising, as Ledóchowski took extreme care to "not leave any traces of written work that could be incriminating in cases of persecution or raids, especially if the matters did not directly involve the Society." Letter dated July 30, 1973, quoted in Passelecq and Suchecky, L'encyclique cachée de Pie XI, 59.

63 Les Carnets du cardinal Alfred Baudrillart (29 novembre 1935-11 avril 1939), ed. Pierre Christophe (Paris: Éditions du Cerf, 1996), 469. 
shared this obsession with the Communist danger, though. French Jesuits were reluctant to work with Lettres de Rome. "The Fathers designated in each French province for the fight against atheism have sent little or nothing to Lettres de Rome editor Fr. Ledit," the general complained in February $1936 .{ }^{64}$ As the Twenty-eighth General Congregation approached, there was a push to renew the strategy on Communism. Northern Belgian Provincial Maurice Schurmans (1901-70) advocated for a positive attitude "in the crucial fight against Communism [...] contrary to the former liberal attitude that often surrounds those in affluent, even Christian, circles. This oppositional stance is negative, fruitless, selfish, and incomprehensible." ${ }^{65}$ The 1938 Congregation was the second, and last, that Ledóchowski convened during his long term as general. On April 13, 1938, Ledóchowski delivered a two-hour speech outlining his strategy on apostolate techniques (Apostleship of Prayer and Marian Congregations), which could only irritate the Society's progressive wing. ${ }^{66}$ The struggle surrounding production of the twenty-ninth decree illustrates the division of the Society regarding approaches to use in the fight against Communism. The decree developed by Béla Bangha (1880-1940), a Hungarian Jesuit, advocated a return to using modern propaganda such as periodicals, newspapers, radio, and film. He encountered opposition from a group of priests who feared that defining an excessively detailed plan against Communism would simply rekindle attacks against the Society and make taking any action more difficult in countries under totalitarian dictatorships, such as Nazi Germany and Fascist Italy. After attempting to impose amendments to that effect, Ledóchowski surprisingly voted in favor of keeping the initial project intact before Zacheus Maher (1882-1963), American assistant and commission chairman, proposed an amended decree that disregarded concrete proposals. ${ }^{67}$ The cautious side in addressing Nazism and Fascism ended to win, to Ledóchowski's huge relief. The new pope and Ledóchowski completely agreed on this matter. ${ }^{68}$

64 Letter to Arsène Lambert (1888-1953), provincial of Paris, February 9, 1936, ARSI, Secretariatus pro communicatione sociali, 1038.

65 Letter, January 29, 1938, ARsI, Secretariatus pro communicatione sociali, 1038.

66 The draft for this speech is in the Society's archives (ARSI. CG XXVIII, b. 8 [54], Documenta ad historiam internam, fasc. 9, De detrimentis). See also the article by Antal Molnar, "Come debellare il diavolo? Controversie alla Xxviı Congregazione Generale della Compagnia di Gesù intorno alla lotta anticomunista (1938)" in La Chiesa cattolica dell'Europa centro-orientale di fronte al comunismo: Atteggiamenti, strategie, tattiche, ed. András Fejérdy (Rome: Viella, 2013), 61-80.

67 Ibid., 76-78.

68 Before being elected, Cardinal Pacelli used the Jesuits' General Curia to meet with Ledóchowski, whom Pacelli had known for a long time. Ingoni, P. Wlodimiro Ledóchowski, 269-70; Muckermann, Im Kampf zwischen zwei Epochen, 630. 
It would be an understatement to say that Jesuit influence on the church's central government increased considerably following Pius XII's election on March 2, 1939. ${ }^{69}$ The apostolic letter sent by the pope to the Jesuit superior general for the Society's fourth centenary (July 6, 1940) said long on the "respect" and "affection" he had for "St. Ignatius's family." On the role of Jesuits in defending the Catholic faith and the church's sacred rights, and in spreading Christianity across all nations, the pope wrote: "Even a quick examination of your history in each area would reveal a host of glorious deeds that go well beyond your order's commission and deserve to be written in gold letters in the splendor of the Catholic Church."70 "Demonstrations of warmth toward a religious leader have rarely been seen on behalf of one pope, let alone two," noted Giacomo Martina, Italian Jesuit historian. ${ }^{71}$ After twenty-seven years as superior general, Ledóchowksi fell gravely ill and died in Rome on December 13, 1942.

In terms of this investigation in the Roman archives, I have demonstrated the undiscussed influence of Włodzimierz Ledóchowski in the progressive stiffening of the Holy See's attitude towards Soviet Communism in the 1930s. The role taken by the general of the Society and the small team of the Lettres de Rome, which he had gathered around him in the writing of the encyclical Divini redemptoris, is prominent. If the obsessional anti-Communism of Ledóchowski, strongly tinged with anti-Semitism, found a wide echo in the Vatican under the pontificate of Pius XI and initially that of Pius XII, it collided, on the other hand, with internal resistance, in particular within the French-speaking provinces (Belgium and France) where the concern was to present a more positive answer to the Communist threat. These two divergent approaches would come to a head during the general congregation of 1938 , revealing the tensions within the Society of Jesus's leadership.

\section{Translated from French by Dwain Richardson and edited by the JJs team}

69 Cf. Alexandra von Teuffenbach, "Der Einfluss der Jesuiten der Päpstlichen Universität Gregoriana auf Papst Pius XII.," in Katholische Theologie im Nationalsozialismus, vol. 1, ed. Dominik Burkard and Wolfgang Weiss (Würzburg: Echter Verlag, 2011), 395-440.

70 "Dans chacun de ces domaines, un examen même rapide de vos annales fait apparaître une foule de faits si glorieux qu'ils dépassent les limites de votre ordre et méritent d'être inscrits en lettres d'or dans les fastes de l'Église catholique," Documents pontificaux de Sa Sainteté Pie XII, vol. 2, 1940 (Saint-Maurice, Switzerland: Éditions Saint-Augustin, 1961), $232-40$.

71 "On a rarement vu tant de manifestations de sympathie de la part d'un pape, et même de deux, envers un supérieur religieux.” Martina, "Ledóchowski (Wlodimir)," 61. 